\title{
IMPORTANCE OF PROTOZOA AS FOOD TO ZOOPLANKTON AND SOME FISH SPECIES IN LAKE QAROUN, EGYPT
}

Adel A. Mageed, ' Amaal Mohammadein ${ }^{2}$ and Mahmoud Desouky $^{2}$

1-National Institute of Oceanography and Fisheries, El Kanater El Khayria Research Station, Egypt.

2- Zoology Department, Faculty of Science, Zagazig University, Egypt.

Key words: Protozoa, food, zooplankton, fish, Lake Qaroun, Egypt

\section{ABSTRACT}

$T^{\text {he relationship between the protozoan organisms and zooplankton }}$ $I$ in addition to fish predation of Lake Qaroun were herby studied. An experiment was conducted in the aquatic laboratory of Shakshouk Station-Fayoum close to Lake Qaroun using cylindrical fiberglass enclosures of 1000 liters capacity that were filled with water pumped from $0.5 \mathrm{~m}$ depth of Lake Qaroun. The numbers and net population growth and production of the dominant protozoan organisms in absence and presence of small and large- sized zooplankton as well as two native fishes namely, Mugil cephalus and Tilapia zillii were described. The average air and water temperatures were $27.7 \pm 2.1$ and $22.6 \pm 1.1 \subseteq \mathrm{C}$ (mean $\pm \mathrm{SD}$ ) respectively. $\mathrm{PH}$ values ranged from 7.39 to $8.00(7.74 \pm 0.13$, mean $\pm S D)$ while ammonium ranged from $64.39 \mu \mathrm{gl}^{*}$ 1 to $1.05 \mathrm{mgml}^{-1}$ during the experiment. At the start, the protozoan organisms, constituted numerically $48.12 \%$ of total zooplankton organisms that dominated by three species; Tintinnopsis kofoidi, Helicostomella subulata, and Euplots vannus. In the presence of the small-sized organisms (SS), the total protozoan number was decreased. In the presence of small and large sized organisms (SLS) the protozoan number returned to the control level. The impact of the fishes was more pronounce in presence of $M$. cephalus than $T$. zilli compared to the control enclosure. Protozoan organisms were observed in the gut contents of $M$. cephalus and $T$. zilli, representing $14.29 \%$ and $4.69 \%$ respectively. The net population growth (NPG) was higher in control. (2.15 day $\left.{ }^{-1}\right)$ followed by SLS (2.10 day $\left.{ }^{-1}\right)$. NPGR of $T$. kofoidi was the highest especially in presence of the SLS 
(1.18 day $\left.^{-1}\right)$, while its lowest level was recorded in presence of $M$. cephalus $\left(0.63\right.$ day $\left.^{-1}\right)$.

\section{INTRODUCTION}

Recent investigations have shown that processes within the planktonic web are of great significance for limnetic ecosystems. Protozoan organisms represent a dominant component of the microzooplankton in marine waters (Pierce and Turner, 1992). These organisms are a considerable food source for zooplankton in addition to some fishes (Rajas de Mendiola, 1974; Berk et al., 1977; Robertson, 1983; Sanders, 1987). The protozoan community represents an important regulatory component of the ecosystem, enabling it to respond quickly to perturbations and thus ensuring its stability. They are free-swimming planktonic organisms occurring in marine, estuarine and freshwater environments where they feed predominantly on unicellular microplankton (Laval-Peuto and Brownlee, 1986). Tintinnid ciliate protozoans constitute a major fraction, by number of many microzooplankton communities (Heinbokel and Beers, 1979; Beers et al. 1980). Qualitative analyses have shown that tintinnids feed mainly on bacteria (Hollibaugh et al., 1980), dinoflagellates (Stoecker et al., 1981) and smaller tintinnids (Blackbourn, 1974).

However, the general importance of protozoans as a food source for rotifers and copepods that constitute a major component of planktonic habitats, has seldom been evaluated in Qaroun Lake. Mechanisms governing fluctuations in protozoan ciliate populations of Lake Qaroun remain unclear. The present work aims to reveal the relationship between these organisms and the small-and large-sized zooplankton in addition to fish predation. Furthermore, determination of the net population growth of the dominant protozoan organisms in the absence and presence of the small- and large-sized zooplankton in addition to two native fishes (Mugil cephalus and Tilpia zilli) in Lake Qaroun might clarify the importance of such protozoans as food for these organisms.

\section{MATERIAL AND METHODS}

An experiment was conducted in the aquatic laboratory of Shakshouk Station -Fayoum, close to Lake Qaroun during April 
1998, and continued for seven days (the community started to decrease in number after six days). Five cylindrical fiberglass enclosures of 1000 liters capacity each, were filled with water pumped from $0.5 \mathrm{~m}$ depth of Lake Qaroun. The steps of the experiment are shown in table (1).

Table (1): The different treatments during the experiment

\begin{tabular}{|c|c|c|}
\hline Enclosures & Treatments & Contents \\
\hline Control & Filtration with $55 \mu \mathrm{m}$-mesh net & Protozoa \\
\hline SS & Filtration with $100 \mu \mathrm{m}$-mesh net & $\begin{array}{l}\text { Protozoa and small sized zooplankton } \\
\text { (nauplius larvae and rotifers) }\end{array}$ \\
\hline SLS & Lake water without treatment & $\begin{array}{l}\text { Protozoa and small-and large-sized } \\
\text { zooplankton (rotifers, nauplius larvac, } \\
\text { copepodites and adult stage of } \\
\text { copepods) }\end{array}$ \\
\hline M. ce & $\begin{array}{l}\text { Lake water without treatment } \\
\text { and } 12 \text { fishes of the same size } \\
\text { category }\end{array}$ & $\begin{array}{l}\text { Protozoa, small- and large-sized } \\
\text { zooplankton and Mutgil cephalus }\end{array}$ \\
\hline T. zilli & $\begin{array}{l}\text { Lake water without treatment } \\
\text { and } 12 \text { fishes of the same size } \\
\text { category }\end{array}$ & $\begin{array}{l}\text { Protozoa, small- and large-sized } \\
\text { zooplankton and Tilapia zilli }\end{array}$ \\
\hline
\end{tabular}

Twenty liters were daily filtered from each enclosure using $20 \mu \mathrm{m}$-mesh net. The filtered organisms were preserved in $4 \%$ neutral formalin, and then identified according to Tuffrau (1960), Bick (1972) and Harrison and Corliss (1991).

The water $\mathrm{pH}$ and temperature were measured by digital Orion pH meter (model 201) in the enclosures directly. Concentration of ammonium $\left(\mathrm{NH}_{4}\right)$ was measured according to standard methods of American Public Health Association (APHA, 1980). The gut contents of the fishes were also analyzed.

Population growth rates (r) of the dominant protozoan species were calculated from the changes in abundance (per day) by Gauld's equation (1951), assuming exponential growth $r=\ln \{N(t) / N(0)\} /$ $t$, where $N(0)$ and $N(t)$ are the mean number of ciliates at the start and the end of the experiment respectively, and " $t$ " is the duration time of the experiment. 


\section{RESULTS AND DISCUSSION}

\section{Physicochemical parameters}

Both air and water temperatures were nearly constant during the time course of the experiment, with average of $27.7 \pm 2.1$ and $22.6 \pm 1.1^{\circ} \mathrm{C}$ (mean $\pm \mathrm{SD}$ ) respectively. The $\mathrm{pH}$ values ranged from 7.39 to $8.00(7.74 \pm 0.13$, mean $\pm S D)$. The variation was narrow in the first three days then stabilized.

Ammonium ranged from $64.39 \mu \mathrm{gl}^{-1}$ to $1.05 \mathrm{mg}^{-1}$ during the experiment. The maximum values were recorded during the last day (seventh day) of the experiment, especially in the fish enclosures (Fig. 1). These increases may be due to: (1) regeneration of ammonium by protozoan and zooplankton organisms. In this respect, Korstad (1983) studied nutrient regeneration by zooplankton in Southern Lake Huron (USA), and found that zooplankton regenerate $23.28 \mu \mathrm{g} \mathrm{N}$ (mg dry wt)- ${ }^{1}$ day $^{-1}$. Moreover, Janik (1989) measured the rates of ammonium released by the natural zooplankton assemblages in Lake Castle (California), and found that zooplankton provided $30.7 \mu \mathrm{g} \mathrm{N}$ (mg dry wt) ${ }^{-}$day $^{-1}$. (2) accumulation of the dead organisms. Protozoans are usually short-lived (1-2 days) (Buskey et al, 1993). Rotifers can persist from 1-7 days, while copepods persist for a matter of days or weeks according to the instar (Payne, 1986). (3) the fish faeces may also responsible for the increase of ammonium in fish enclosures.

\section{Analysis of organisms}

\section{A. In the control enclosure:}

At the start of the experiment, the lake prorozoan organisms represented numerically $48.12 \%$ of total zooplankton organisms and were dominated by three species; namely Tintinnopsis kofoidi, Helicostomella subulata, and Euplots vannus. Copepods form $39.20 \%$ (of the total zooplankton number) and dominated by the juvenile stages of Paracartia latesetosa. It was followed by rotifers $(7.51 \%)$ that dominated by Brachionus plicatilis (forming about $98 \%$ of the total rotifer number). These results are nearly similar to those reported by Khalifa (1994) and Mageed (1998) in Lake Qaroun.

The total number of protozoan organisms increased gradually up to the fifth day; thereafter it increased dramatically on the sixth day, and then started to decrease on the last day (Fig. 2A). This decrease may be due to the increase of ammonium concentration during this period. 


\section{B-In presence of the small-sized organisms (SS)}

The increases in total protozoan number as well as the most dominant protozoan species were lower than control in SS enclosure. The number of $H$. subulata was increased after the fifth day only (Fig. 1B). Such decease in protozoan organisms was conconitant with the increase in rotifers and copepods (Fig 7). This means that both rotifers and nauplius larvae have some regulatory effect on the protozoan organisms. In this respect, Arndt (1991) revealed that, ciliates should be a common part of the food of most rotifer species. Gilbert and Jack (1991) had also found that, in the absence of edible algal food, rotifers might extensively prey ciliates in natural plankton communities, ingesting 25 to 50 individuals daily. Taniguchi and Kawakami (1985) have cultivated the tintinnid Favella taraikaensis and the rotifer Synchaeta vorax with Prorocentrum as the only source of food. They found competition between tintinnids and rotifers. Ingrid et al (1996) stated that the early stages of copepods might compete for food with ciliates, so it can decrease ciliates indirectly.

\section{C-In presence of small and large sized organisms (SLS)}

The total protozoan number was similar to the control over the time course of the experiment. However, the number of $T$. kofoidi decreased in presence of SLS than in the control; whereas for $H$. subulata the reverse was reported. For E. vannus, the number decreased gradually up to the third day and increased again during the fourth day where it reached its maximum number. Thereafter, its number returned to the control level up to the seventh day

Burns and Schallenberg (1996) and Wickham (1998) considered protozoans as important food for copepods, whereas Ingrid et al (1996) and Merrell \& Stoecker (1998) found that one should expect an ontogenetic shift from strong competition with ciliates in early life history stages of copepods to weaker competition in adult stages. Copepods, the main predators of tintinnids, may also consume rotifers (Egloff, 1988; Pinel-Alloul, 1995 and Lam-Hoai et $a l, 1997)$. The feeding of copepods on rotifers decreased predation of Protozoa by copepods in presence of rotifers.

\section{In presence of Fishes}

The impact of the fishes on protozoa was more pronounced in presence of $M$. cephalus than $T$. zilli compared with the control 
enclosure (Figs 3 \& 4). The number of protozoan organisms decreased in presence of these fishes with similar trends for the three protozoan species. The presence of these planktivorous fish leads to decrease in macrozooplankton population. Thus, the small zooplankton has increased and fed on the protozoan organisms or compete with them on food.

Analysis of gut contents of $M$. cephalus revealed that adult copepods are the main item in the gut (representing $36.74 \%$ of total zooplankton number in the gut). They were followed by rotifers and nauplius larvae. Protozoan organisms were also observed in the gut content of $M$. cephalus (Table 2). They represented $14.29 \%$ of the gut content. These results are in agreement with Zimann et al. (1975) who stated that, copepods were found to be the most important food items in the gut content of grey mullet in the Haif Bay region. For $T$. zilli; rotifers, nauplius larvae and adult copepods represented $37.5 \%$, $26.56 \%$ and $25 \%$ of the gut contents respectively, while protozoans represented only $4.69 \%$. In this concern, Shabrawy and Fishar (1999) revealed that, nauplius larvae and adult Paracartia latisetosa were the most important food items in the gut content of mullet of Lake Qaroun. The decrease in protozoa in the gut contents of the species may be due to the very fast digestion of protozoa.

\section{Net population growth rates (NPGR, $\mathrm{rday}^{-1}$ ):}

Several methods have been used to measure population growth rate of ciliates, including extrapolations (Leakey et al. 1992), frequency of dividing cells (Heinbokel, 1987), and incubation of sizefractionated water samples (Gilron and Lynn, 1989). The later method was applied in the present investigation since it is convenient for use in multispecies assemblages. This approach has assumed that all potential ciliate predators are removed by filtration. However, several predators of the same size of ciliates may pass through the filters (Doland, 1991). The net growth rates estimated by this method should therefore be considered conservative (Verity, 1986).

Total net population growth rate of protozoan organisms during the experiment was higher in control $\left(2.15\right.$ day $\left.^{-1}\right)$ followed by SLS enclosure (2.1 day $\left.^{-1}\right)$. NPGR increased to the maximum value in the sixth day (Fig. 9).

NPGR of T. kofoidi was the highest especially in presence of the SLS (1.18 day $\left.{ }^{-1}\right)$, while its lowest was recorded in presence of $M$. cephalus $\left(0.63\right.$ day $\left.^{-1}\right)$. For $H$. subulata, the net population growth rate was higher in presence of the SLS than the control, while it decreased 
in presence of fishes especially $M$. cephalus. Net population growth rate for $E$. vannus was the lowest. $\left(0.47\right.$ day $\left.^{-1}\right)$ in the presence of $T$. zilli. The growth rates of $E$. vannus was negatively influenced by $M$. cephalus $\left(-0.39\right.$ day $\left.^{-1}\right)$.

Net protozoans growth rates of total dominant protozoan organisms ranged from 0.38 to 2.15 day $^{-1}$. They were nearly similar to those reported by Schiewer et al (1990) (1.9day $\left.{ }^{-1}\right)$. Furthermore,Nielsen and Kiorboe (1994) stated that the true planktonic bacterivorous ciliates $<15 \mu \mathrm{m}$ have relatively low growth rates $\left(\sim 0.5\right.$ day $\left.^{-1}\right)$. Ingrid et al. (1996) found that the rotifers have some regulatory effect on the protozoan organisms. They also found that the high specific growth rate for ciliates imply high ability to rapidly increase population size. Ciliates are able to grow 2-20 times faster than copepods under optimal conditions, but they are controlled through predation of copepods on them. (Nielsen and Kiorboe, 1991).

In conclusion, protozoa are important food item for the smallsized and with a lesser extent to large-sized zoopankton. They can also be consumed by the two studied fishes especially $M$. cephalus so that the production of protozoa can be used in feeding of more transplanted Mugil fry in the lake.

\section{REFERENCES}

American Public Health Association (APHA) (1980). Standard methods for the examination of waters and wastewaters, New York, 1193pp.

Arndt, H. (1991). Rotifers as Predators on Components of the Microbial Web (bacteria, heterotrophic flagellates and ciliates). Rotifer-Symposium-VI. Gilbert, Lubzens, and Miracle (eds), 255-256: 231-246.

Beers, J. R.; Reid, F. M. H. and Stewart, G. L. (1980). Microzooplankton population structure in Southern California near shore waters in late spring. Mar. Biol., 60: 209-226.

Berk, S. G.; Brownlee, D. C.; Heinle, D. R.; King, H. J. and Colwell, R. R. (1977). Ciliates as a food source for marine planktonic copepods. Microb. Ecol., 4: 27-40. 
Bick, H. (1972). Ciliated Protozoa. WHO, Geneva,198pp.

Blackbourn, D. J. (1974). The Feeding Biology of Tintinnid Protozoa and some other Inshore Microzooplankton. Ph. D. Thesis, Univ. British Columbia, 224pp.

Burns, C. and Schallenberg, M. (1996). Relative impacts of copepods, cladocerans and nutrients on the microbial food web of a mesotrophic lake. J. Plankton Res, 18: 683-714.

Buskey, E. J.; Coulter, C. and Strom, S. (1993). Locomotory patterns of microzooplankton: Potential effects on food selectivity of larval fish. Bull. Mar. Sci., 53 (1): 29-43.

Doland, J. R. (1991). Guilds of ciliate microzooplankton in the Chesapeake Bay. Estuarine Coastal Shelf. Sci.,33: 137-152.

Egloff, D. A. (1988). Food and growth relations of the marine microzooplankton, Synchaeta cecilia (Rotifera). Hydrobiologia, 157: 129-141.

Gauld, D. T. (1951). The grazing rate of planktonic copepods. J. Mar. Biol. Assoc. U. K, 29: 695-706.

Gilbert, J. J. and Jack, J. D. (1991). Rotifers as predators on small ciliates. Rotifer Symposium. VI. Hydrobiologia 255-256: 247-253.

Gilron, G. L. and Lynn, D. H. (1989). Estimates of in situ population growth rates of four tintinnid ciliate species near Kingston Harbour, Jamaica. Estuarine Coastal Shelf Sci., 29: 1-10.

Harrison, F. W. and Corliss, J. O. (1991). Microscopic Anatomy of Invertebrates., 1 : Protozoa, 333-467.

Heinbokel, J. F. (1987). Diel periodicities and rates of reproduction in natural populations of tintinnines in the oligotrophic waters 
of Hawaii, September 1982. Mar. Microb. Food Webs, 2: $1-14$.

Heinbokel, J. F. and Beers, J. R. (1979). Studies on the functional role of tintinnids in the Southern California Bight. IIt. Grazing impact of natural assemblages. Mar. Biol., 52: 2332.

Hollibaugh, J. T. Fuhrman, J. A. and Azam, F. (1980). Radioactively labeling of natural assemblages of bacterioplankton for use in trophic studies. Limnol. Oceanogr., 25: 172-181.

Ingrid, G.; Andersen, T. and Vadstein, O. (1996). Pelagic food webs and eutrophication of coastal waters: Impact of grazers on algal communities. Marine Pollution Bulletin., 33(1-6): 2235.

Janik, J. J. (1989). Nutrient recycling in Castle Lake, California: Phytoplankton-zooplankton interaction. Dess. Abst. Int. Pt. B-Sci. and Eng., 49(8): 141pp.

Khalifa, N. S. (1994). Ecological Studies on Zooplankton of Lake Qaroun. M. Sc. Thesis, Fac. Sci. Cairo Univ., 167pp.

Korstad, J. (1983). Nutrient regeneration by zooplankton in Southern Lake Huron. J. Great Lakes Res., 9(3): 374-388.

Lam-Hoai, T.; Rougier, C. and Lasserre, G. (1997). Tintinnids and rotifers in a northern Mediterranean coastal Jagoon. Structural diversity and function through biomass estimations. Mar. Ecol. Prog. Ser., 152: 13-25.

Laval-Peuto, M. and Brownlee, D. C. (1986). Identification and systematics of the tintinnid (Ciliophora): Evaluation and suggestions for improvement. Ann. Inst. Oceanogr., Paris, 62(1): 69-84. 
Leakey; R. J. G.; Burkill, P. H. and Seleigh, M. A (1992). Planktonic ciliates in Southampton Water: Abundance, biomass, production, and role in pelagic carbon flow. Mar. Biol., 114: 67-83.

Mageed, A. A. (1998). Zooplankton of Lake Qaroun (Fayoum-Egypt) during 1996. Bull. Nat. Inst. Oceanogr. \& Fish., ARE. 24: 161-177.

Merrell, J. R. and Stoecker, D. K. (1998). Differential grazing on protozoan microplankton by developmental stages of the calanoid copepod Eurytemora affinies Poppe. J. Plankton Res., 20: 289-304.

Nielsen, T. G. and Kiorboe, T. (1991). Effects of a storm event on the structure of the pelagic food web with special emphasis on planktonic ciliates. J. Plank. Res., 13: 35-51.

Nielsen, T. G. and Kiorboe, T. (1994). Regulation of zooplankton biomass and production in a temperate, coastal ecosystem. 2. Ciliates. Limnol. Oceanogr., 39(3): 508-519.

Payne, A. J. (1986). The Ecology of Tropical Lakes and Rivers. John Wiely \& Sons Chichester, New York, Toronto, Brisbance, and Singapore, 300pp.

Pierce, R. W. and Turner, J. T. (1992). Ecology of planktonic ciliates in marine food webs. Rev. Aquat. Sci., 6: 139-181.

Pinel-Alloul, B. (1995). Les invertebres predateurs du zooplancton. In: "Limnologie Generale" Pourriot R, Meybeck M (eds). Masson \& Cie, Paris, p 541-564.

Rajas de Mendiola, B. (1974). Food of the larvae Anchoveta engraulis ringiens J. In Blaxter. J. H. S. (ed.). "The Early Life History of Fish". Spring-Verlag, New York, 277-285.

Robertson, J. R. (1983). Predation by estuarine zooplankton on tintinnid ciliates. Estuar. Coast. Mar. Sci., 16: 27-36. 
IMPORTANCE OF PROTOZOA AS FOOD TO ZOOPLANKTON 69 AND SOME FISH SPECIES IN LAKE QAROUN, EGYPT

Sanders, R. W. (1987). Tintinnids and other microzooplankton seasonal distributions and relationships to resources and hydrography in a marine estuary. J. Plankton Res. 9 (1): 6577.

Schiewer, U. H.; Anndt, G.; Jost, R. H. and Wasmund, N. (1990). Carbon flux dynamics in a shallow eutrophic estuary. Limnologica, (Berlin), 20(1):95-100.

Shabrawy, G. M. and Fishar, M. R. (1999). Zooplankton consumption and feeding habits of mullet fry in Lake Qaroun (Egypt). In: The Role of Science in the Development of Egyptian Society and Environment. Zagazig Univ., Fac. Sci. (Benha). 130-134.

Stoecker, D. K.; Guillard, R. L. and Kavee, R. M. (1981). Selective predation by Favella ehrenbergi (Tintinnida) on and among dinoflagellates. Biol. Bull., 160: 136-145.

Taniguchi, A. and Kawakami, A. (1985). Feeding activity of a tintinnid Favella taraikaensis and its variability observed in laboratory cultures. Mar. Microb. Food Webs, 1: 17-34.

Tuffrau, M. (1960). Revision du genre Euplotes, fondee sur la comparaison des structures superficielles. Hydrobiologia. 15(1-2): 1-77.

Verity, P. G. (1986). Growth rates of natural tintinnid populations in Narragansett Bay. Mar. Ecol. Prog. Ser., 29: 117-126.

Wickham, S. A. (1998). The direct and indirect impact of Daphnia and Cyclops on a freshwater microbial food web. J. Plankton Res., 20: 739-755.

Zimann, L.; Berdugo, V. and Kimor, B. (1975). The food and feeding habits of early stages of grey mullets. 
Table (2): Gut contents of Mugil cephalus and Tilapia zilli of the experiment

\begin{tabular}{|l|l|l|}
\hline & Mugil cephalus & Tilapia zilli \\
\hline Protozoa & $14.29 \%$ & $4.69 \%$ \\
\hline Rotifera & $19.39 \%$ & $37.5 \%$ \\
\hline Nauplius larvae & $36.74 \%$ & $26.56 \%$ \\
\hline Copepodite stages & $11.23 \%$ & $6.25 \%$ \\
\hline Adults of copepods & $18.37 \%$ & $25 \%$ \\
\hline
\end{tabular}

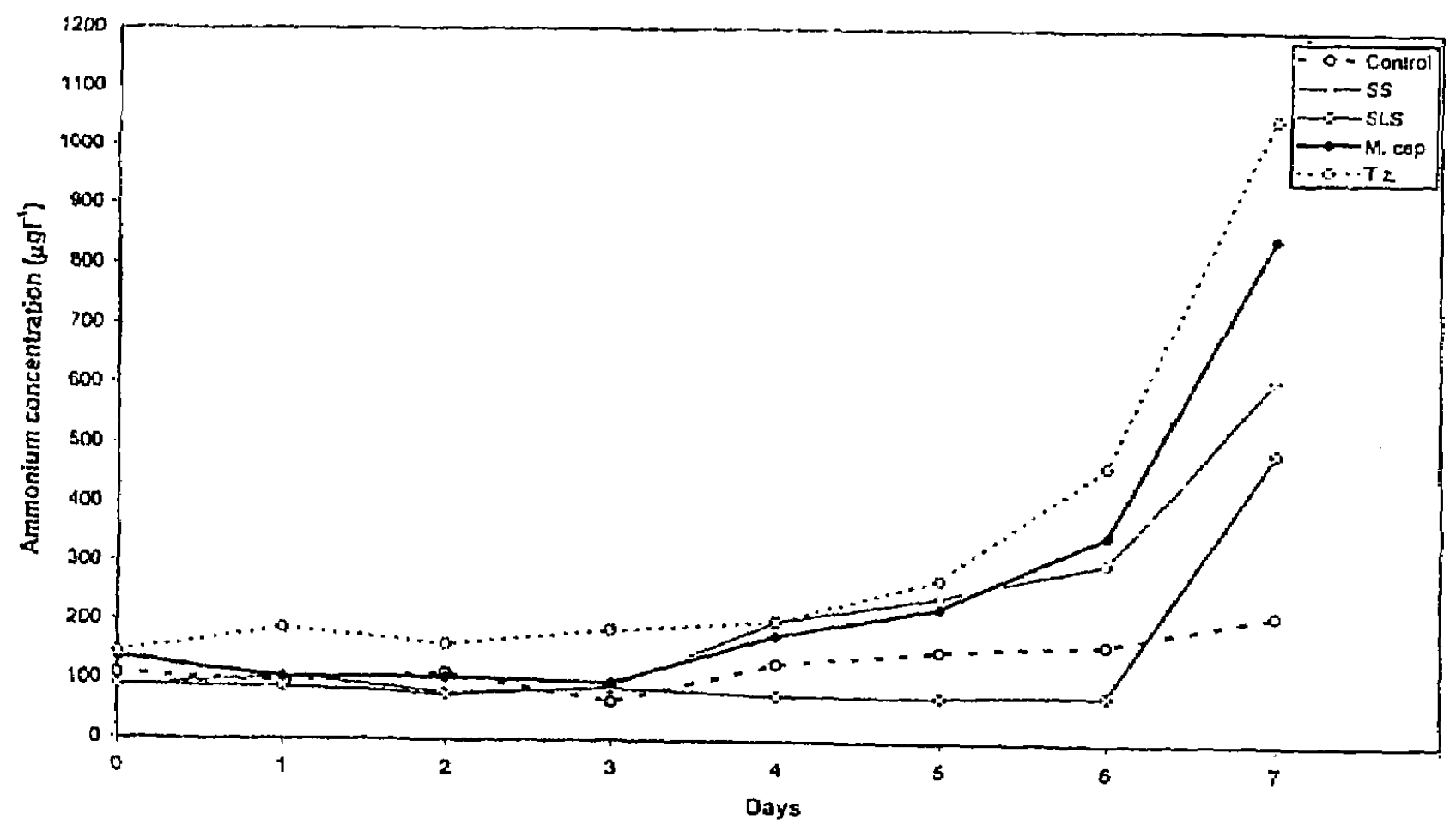

Fig. (1): Ammonium concentration $\left(\mu \mathrm{gl}^{-3}\right)$ in the different enclosures over 7 days 


\section{IMPORTANCE OF PROTOZOA AS FOOD TO ZOOPLANKTON 71 AND SOME FISH SPECIES IN LAKE QAROUN, EGYPT}

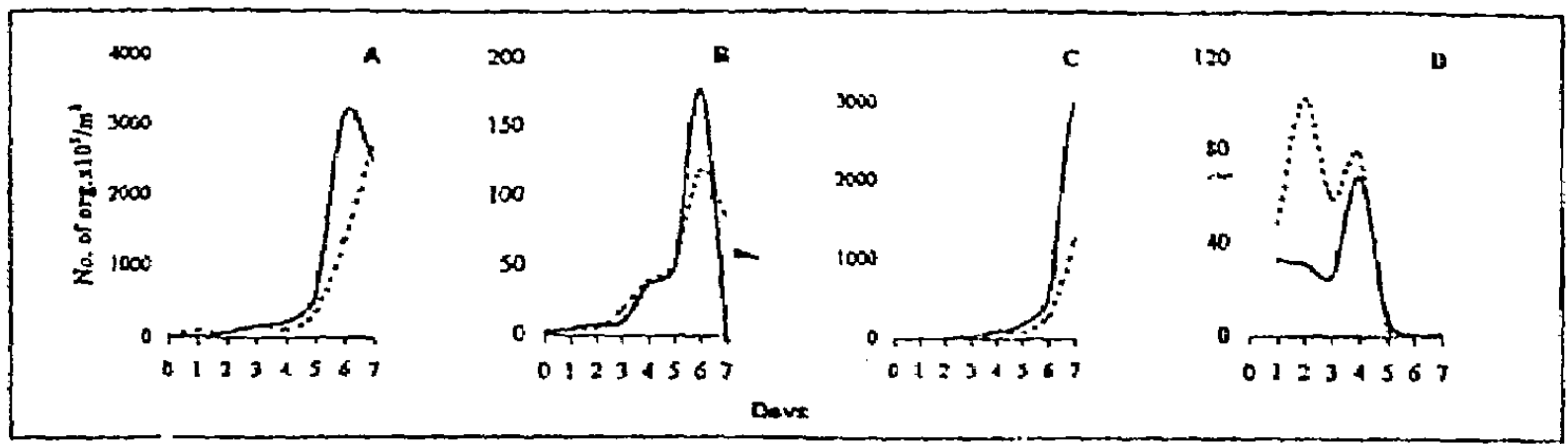

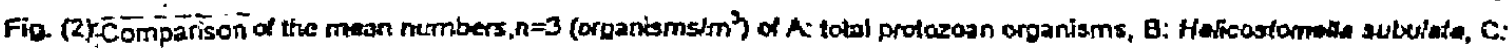
Tintinhopsis kafoidi and D: Euplatus vamess in control (continued line) and small-bodiod enclowures (dashod lino)

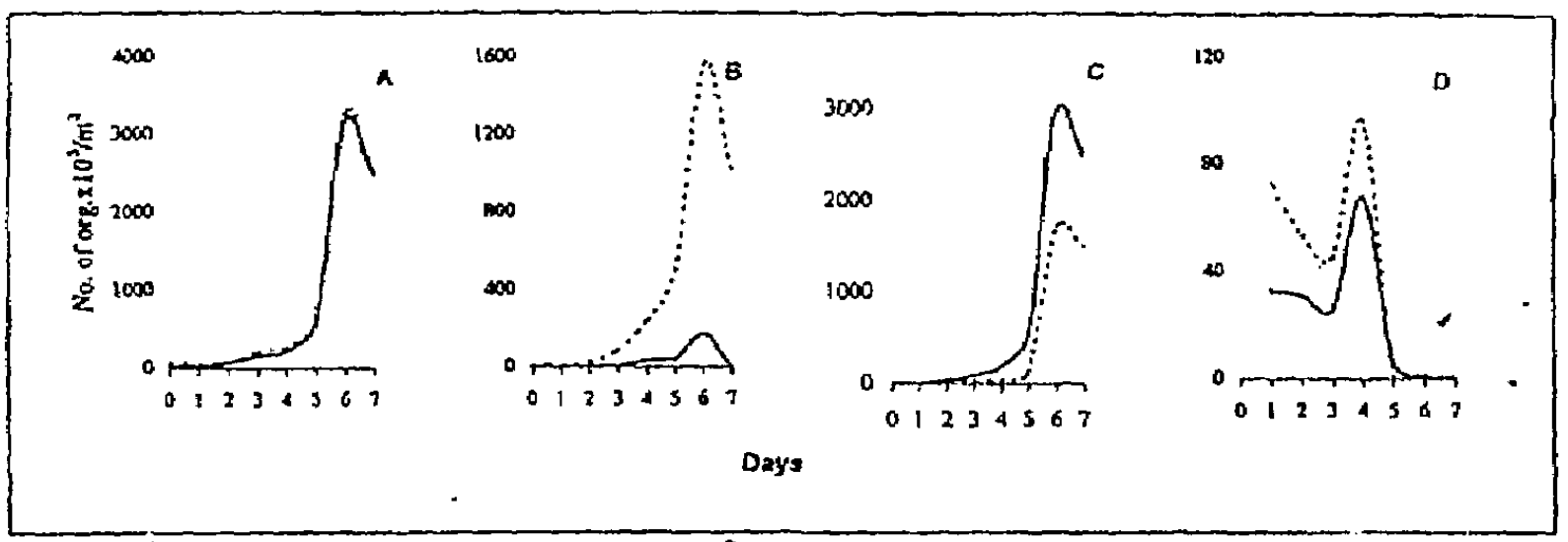

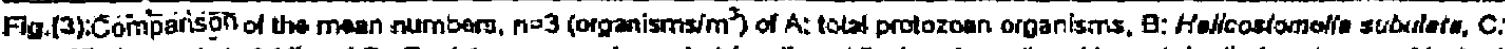

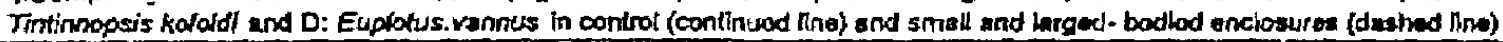

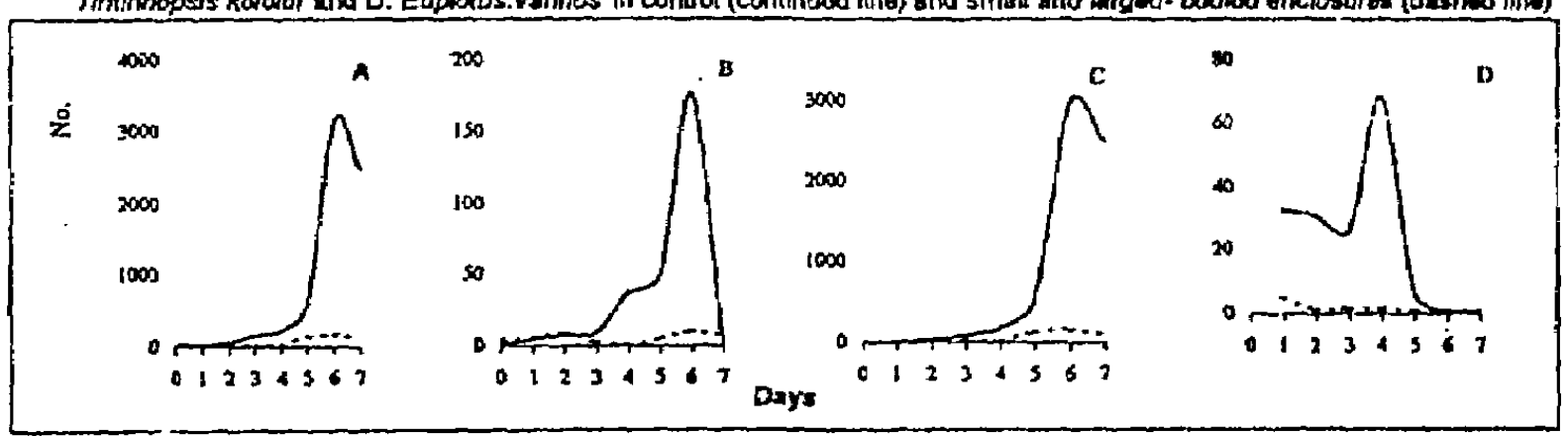

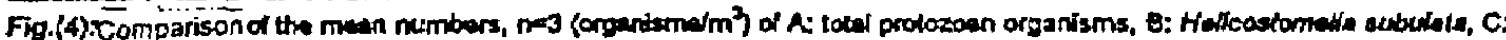

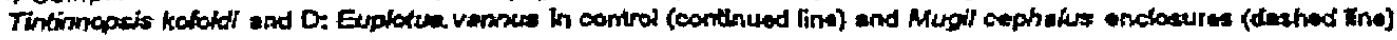

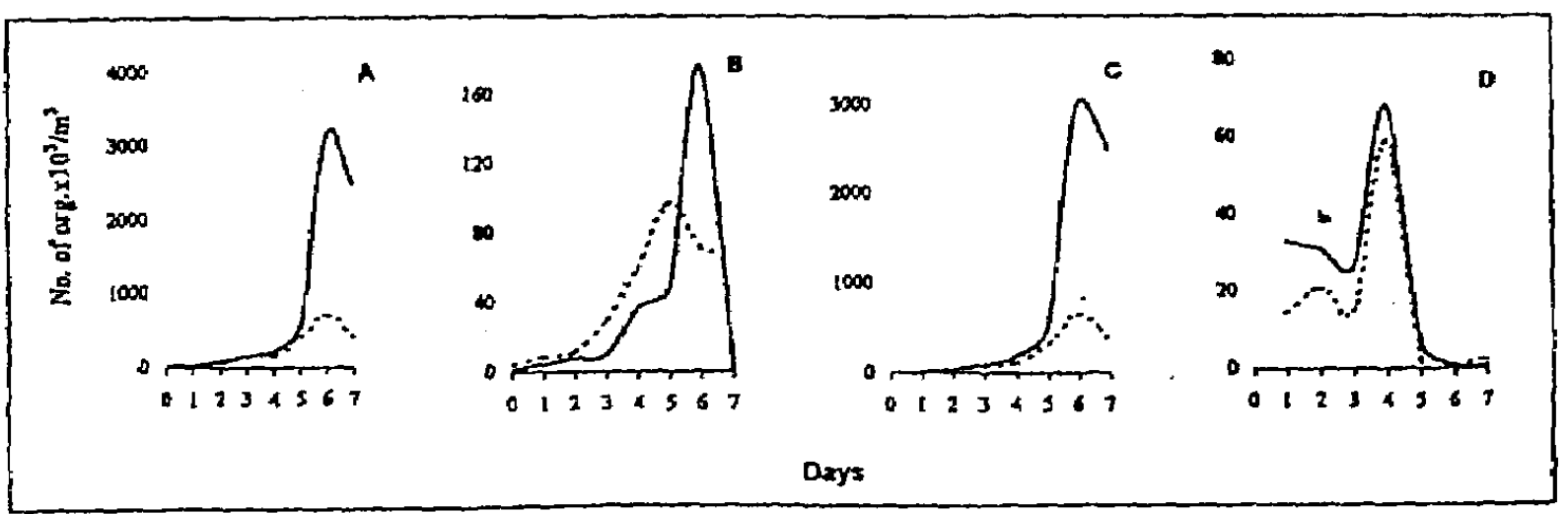

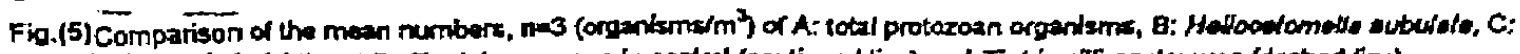

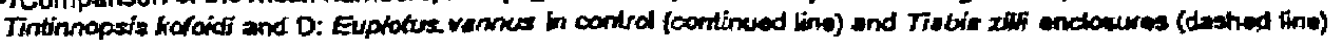




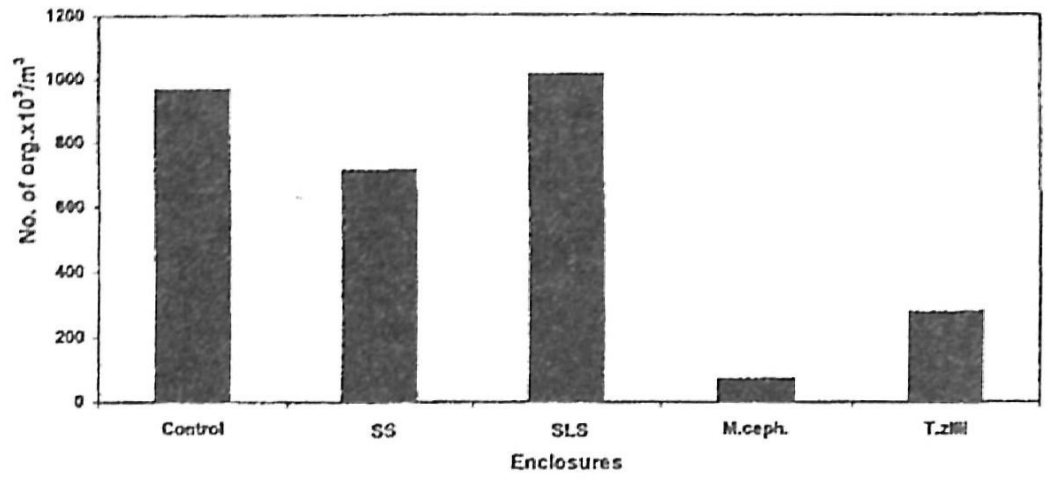

Fig.(6): Average number of the common protozoan organisms (org. $/ \mathrm{m}^{3}$ ) in the different enclosures

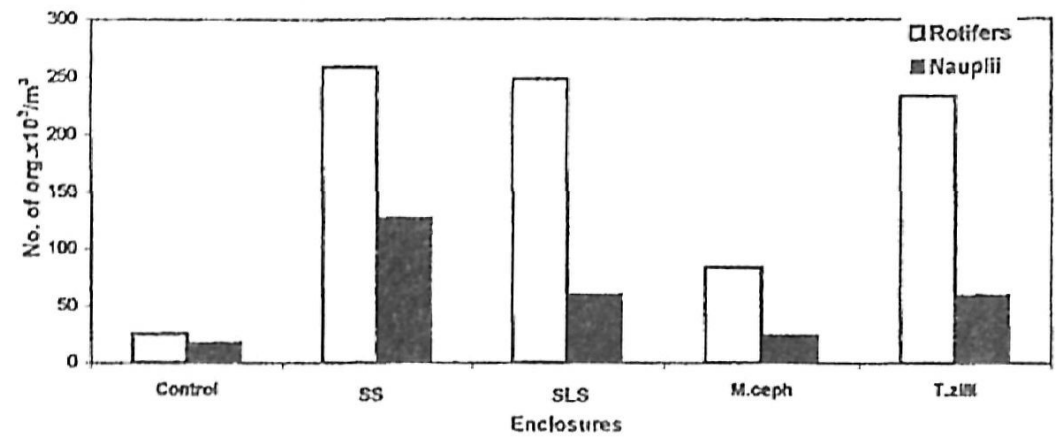

Fig.(7): Average number of the common small-sized zooplankton ( $\left.\mathrm{org} . / \mathrm{m}^{3}\right)$ in the different enclosures

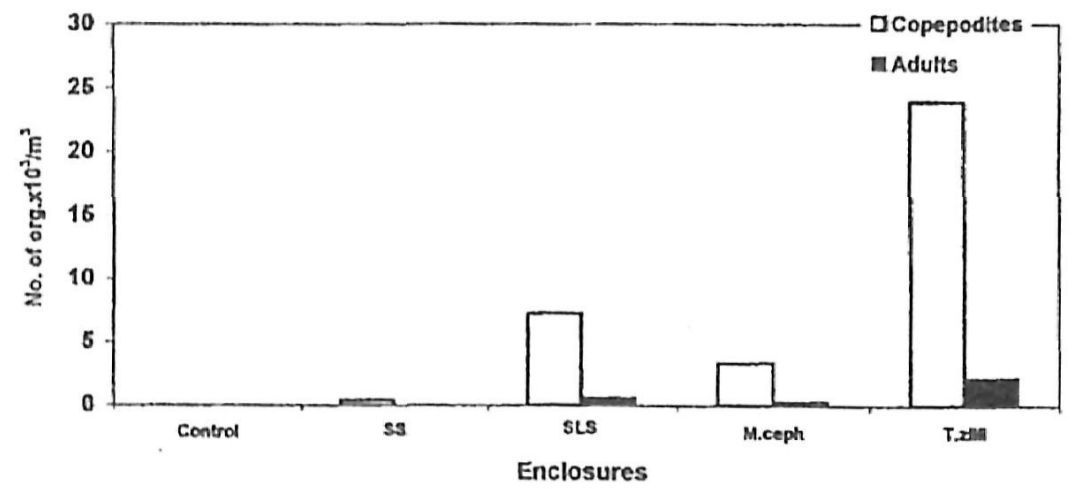

Fig.(8): Average number of the common large -sized zooplankton $\left\{\right.$ org. $/ \mathrm{m}^{3}$ ) in the different enclosures. 


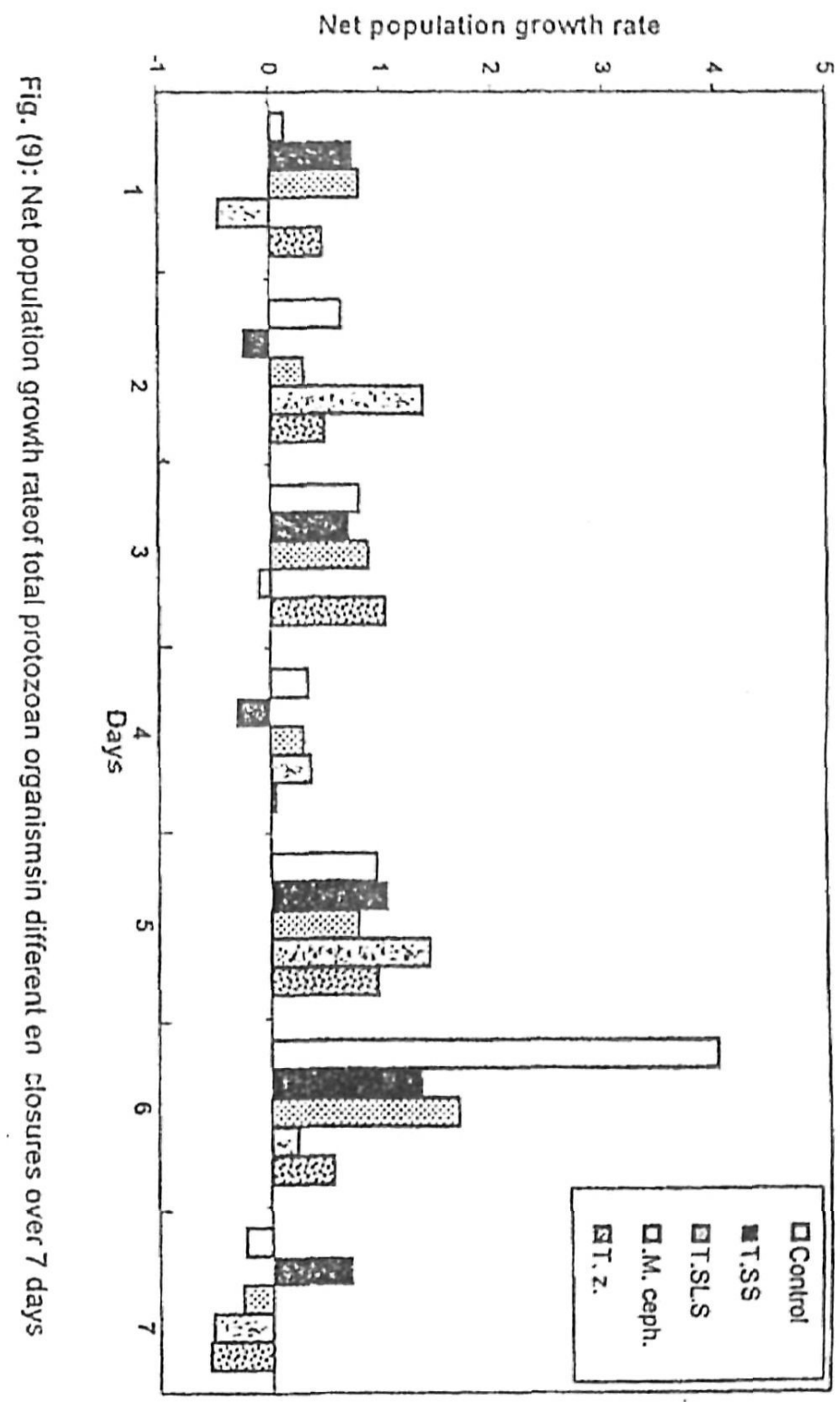

